EDITORIAL

\title{
Invitation to Attend the Fall Meeting of the Swiss Chemical Society in Lausanne, on Thursday, October 13th, 2005
}

On behalf of the Swiss Chemical Society and of the Local Organizing Committee, we are pleased to invite you to attend the SCS Fall Meeting 2005. Following the tradition of alternating locations of this event, the Ecole Polytechnique Fédérale de Lausanne (EPFL) is proud to host this year's meeting on its campus.

The Swiss Chemical Society Fall Meeting is the largest annual scientific congress organized in Switzerland. This event offers a unique opportunity for graduate students, post-doctoral researchers and scientists of all levels, from both academia and industry, to share the results they have obtained in their research projects. It also allows all generations of chemists to exchange ideas, often generating the seeds for new projects and collaborations.

More than 360 scientific contributions have been accepted in the fields of Analytical Chemistry, Medicinal Chemistry, Inorganic and Coordination Chemistry, Organic Chemistry, Physical Chemistry and Computational Chemistry. As in past meetings, there will be a jury to select the best poster and oral presentations in each session, for which prizes will be awarded. We hope that the following program will interest you, and we encourage you to come to Lausanne and participate - it is this very thing that will make the 2005 Fall Meeting of the Swiss Chemical Society a grand success. We look forward to seeing you there.

Prof. Heinz Berke

Chairman of the Division

Chemical Research
Prof. Jacques-E. Moser

Chairman of the Organizing Committee 


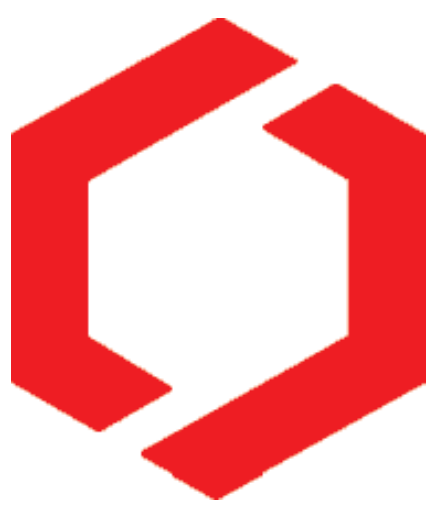

\section{SCHWEIZ. CHEMISCHE GESELLSCHAFT SCG}

SOCIETE SUISSE DE CHIMIE

DIVISIONS

ANALYTICAL CHEMISTRY

CHEMICAL RESEARCH

MEDICINAL CHEMISTRY
DIVISIONEN

ANALYTISCHE CHEMIE

CHEMISCHE FORSCHUNG

MEDIZINISCHE CHEMIE
DIVISIONS

CHIMIE ANALYTIQUE

RECHERCHE CHIMIQUE

CHIMIE THERAPEUTIQUE

\section{Fall Meeting 2005 Herbstversammlung 2005 Assemblée d'automne 2005}

Thursday, October 13th, 2005

Donnerstag, 13. Oktober 2005

Jeudi, 13 octobre 2005

\section{Lausanne}

